\title{
Mina Sami* \\ French Firms and COVID-19: Do the Debt Status, Crisis Management System, and Monetary Policy Play a Role?
}

https://doi.org/10.1515/jbnst-2020-0052

Received October 8, 2020; accepted January 4, 2021

\begin{abstract}
This study has two main objectives: first, it assesses the effect of outbreak pandemic diseases on the French firms' stock returns by considering the sector of activity as the main center of analysis. Second, it investigates the role of the crisis management system, firm debt strategy, and monetary policy in dealing with the adverse shocks of the major outbreak of the COVID-19. The study results can be summarized as follows: (1) the daily growth in COVID-19 cases and deaths are associated with lower stock returns of the listed firms, especially for the firms operating in the energy, industrial and health care sectors. In contrast, telecommunication and consumer sectors are not significantly affected. (2) The pandemic's adverse effect is much more tolerant with the French firms with an efficient crisis management system and low long-term debt commitments than the firms that do not have such a system and engaged with long term debts. (3) Euribor rates and monetary policy are still playing an essential role during the pandemic period.
\end{abstract}

Keywords: stock returns, COVID-19, pandemic, debt status, crisis management systems

JEL-Classification: C3, D22, E5, H12

\section{Introduction}

The broad literature that concerns the capital markets reveals that the stock market returns are responsive to various major events. Historically, such returns are always affected by environmental circumstances (Degiannakis et al. 2013; Limkriangkrai et al. 2016), political events (Charfeddine and Al Refai 2019) and disasters (Capelle-Blancard 2010; Kowalewski and Śpiewanowski 2020).

The spread of worldwide pandemics such as H1N1, SARS, EVD, and COVID-19 is one of this century's main features. Therefore, several studies appeared to assess

*Corresponding author: Mina Sami, Assistant Professor, Department of Economics, The American University in Cairo, New Cairo, Egypt, E-mail: mina_sami@aucegypt.edu 
these events' impact on the stock market returns (Sharif et al. 2020). However, this research area is still in progress, mostly if we focus on the firms' sector of activity, crisis management system, and debt status after the spread of COVID-19. Compared to the studies currently in progress, this study aims to examine four main questions: How does the COVID-19 affect the listed firms' stock market returns in France? Which sectors are the most vulnerable to respond negatively to pandemics? How does the pandemic impact the firms that are more committed to long a debt status relative to the firms with a short-term debt status? Does the crisis management system play a significant role in reducing the pandemic's adverse effect on the stock returns?

On January 24, 2020, the first case of coronavirus in Europe was detected in Bordeaux, France, with Chinese tourists (Bernard-Stoecklin 2020). On February 14, Paris city recorded the first death outside Asia and Europe (France Info 2020). By March 17, the government announced quarantine, borders were closed, and economic activity diminished. By the first quarter of the year, France suffered from a recession (INSEE 2020). Since May 11, the country's lockdown has been relaxed, and economic activity has started to catch-up. However, the COVID-19 outbreak has adversely affected investments and business activity in France.

This study assumes three central hypotheses: First, COVID-19 has precise results on the sector of activity in which it operates. Some sectors are expected to be less affected such as the telecommunication sector. In contrast, others are expected to be substantially affected, such as the industrial and energy sectors. According to Bloom et al. (2018), different sectors are likely to respond disproportionately to unexpected major events, including the outbreak of pandemics. Second, the adverse pandemic effect is much more tolerant with the firms with less long-term debt commitments.

Furthermore, capital structure literature suggests that debts are an essential source of finance; however, it may significantly impact the firm's financial obligations (D’Amato 2019; Sami et al. 2020). During a pandemic, the profitability indicators are very likely to change, and sometimes the firm may face a period of loss. If we consider the expected loss and the burden of the firms' debt commitments, the situation is expected to be more complicated. When the long-term debt commitments are low, the pandemic's negative effect on the stock returns is expected to be much more tolerant. Third, crisis management plays a vital role in reducing pandemics' negative impact on the listed firms' stock returns. Crisis management allows firms to adopt various strategies that guarantee the best management practices implementation such as scenario planning, efficient communication from managers to employees, identifying the market gaps that help to reposition the firms in the market (World Bank 2020). 
This study's originality is to assess pandemics' impact, especially COVID-19, on the listed firms' stock market returns in France. In particular, this assessment (1) distinguishes the effect across the different sectors in the economy (2) investigates the role of the debt status and crisis management in reducing the adverse impact of the pandemic on the stock returns (3) explores the role of Euribor rates and monetary policy during pandemic periods.

The rest of the paper is organized as follows. The next section presents the related Literature Review. Section 3 provides data and descriptive statistics. The fourth section presents the methodology and empirical results. Robustness Checks are presented in section 6 , followed by the conclusion.

\section{Literature Review}

The Stock market is considered as one of the most responsive markets for major unexpected events (He et al. 2020). The existing research papers on the impact of major events on the economy and financial markets has consistently focused on political and security affairs, natural disasters and financial crises (Al-Awdahi et al. 2020; Capelle-Blancard 2010; Charfeddine and Al Refai 2019; Kowalewski and Śpiewanowski 2020; Zhang et al. 2020).

However, there exists a limited number of research papers that focus on unexpected health events. Some studies focus on the regional/specific country effects, for example, Chen et al. (2018) showed that SARS harms the financial markets in the Asian region. Using a panel of 48 countries, Barro et al. (2020) found that the coronavirus and the Great Influenza pandemic negatively affected the stock returns, especially the government bills. Akhtaruzzaman et al. (2020) examine the impact of the COVID-19 outbreak on the financial correlation between China and G7 countries, where they found a dynamic correlation in the financial markets in this region (Al-Awadhi et al. 2020).

While other studies focus on some industries, Sobieralski (2020) focused on the airline industry and demonstrated the critical losses for the airline labor in the United States after the COVID-19. The study of Ayati et al. (2020), concerned with the pharmaceutical sector, showed what the industry has suffered from a slowdown in growth due to COVID-19.

Furthermore, the sector is expected to assist significant shifts in the long run due to the lessons learned from this pandemic. Qin et al. (2020) focused on the Oil industry sector, which showed that this sector is one of the top sectors that assisted substantial adverse shocks due to COVID-19.

This paper extends the previous literature review by (1) considering France, which has been somehow overlooked by the current studies, as the center of the 
study (2) studying the impact of the pandemic on the different sectors of the economy (3) investigating the role of the crisis management system and debt status during the major pandemic shocks.

\section{Data and Descriptive Statistics}

Data has been exported from the Eikon Reuters Database (2020) on listed firms in France, ${ }^{1}$ covering the period from January 23,2020 , to October 30, 2020. The data already includes information for each French firm daily, such as stock market returns, market value and employees. Other firm-level invariant time variables were used, such as the sector of activity, long term debt to market capitalization and crisis management practices. This latest data has been compiled with daily data on COVID-19 exported from www.ourworldindata.org (Roser et al. 2020) for the same period. Finally, daily Euribor rates have been implemented to show the response of stock market returns to changes in the borrow funds rate. Euribor rates data were obtained weekly from the European Banking Federation Internet page at www.euribor.org. Hence, Table 1 presents a summary of sources and the exact definition and measurement of each variable.

Figures in Appendix present the firm variables' variation within the firm's average and over time (Figures A1, A2, and A3). In contrast, the other figures demonstrate the change of the variables over time (Figures A4, A5, and A6). The firm variables have been widely affected over time, especially for March 2020 and May 2020, which includes a significant increase in the new deaths due to COVID-19 (Figure A6).

For the other variables, the monetary policy variable shows that Euribor and the stringency index rates have been changing throughout the COVID-19 period (Figure A4). It is clear that the government adopted changes in rules according to the new cases/deaths during the pandemic crisis, and we note that the stock returns started to decrease significantly, starting from March.

Table 2 presents the data's statistics excluding the top and least 1\% stock returns that showed extreme change. It shows that the stock market returns are highly volatile, reaching a peak of $16 \%$ and a trough of -12.28 . However, the other variables, which are on the firm-level, are dynamically changing, such as the market value variable. In contrast, the employee's variable is considered the least dynamic variable. As a result, having a closer look at Euribor rates, it is evident that the rates were changing during this period, where the change rate decreased to $-8.88 \%$ (from the last week of March to the first week of April). The growth in

1 A sample of the 587 firms used in the study is included in Appendix. See Table A.1. 
Table 1: Definition of the variables.

\begin{tabular}{|c|c|c|}
\hline Variable & Source & Definition \\
\hline Stock return & Eikon Reuters Database & $\begin{array}{l}\text { This variable reflects the daily change in stock } \\
\text { prices in percentage. }\end{array}$ \\
\hline Market value & Eikon Reuters Database & $\begin{array}{l}\text { The variable describes the worth of an asset in } \\
\text { the market. The variable reflects the change daily } \\
\text { in percentage. }\end{array}$ \\
\hline Employees & Eikon Reuters Database & $\begin{array}{l}\text { Employee's variable is calculated as a change } \\
\text { daily in percentage. It reflects that the firm's size } \\
\text { matters and whether a firm downsizes its activ- } \\
\text { ities during the COVID-19 period (Montout and } \\
\text { Sami 2016; Sami and Eldomiaty 2019). }\end{array}$ \\
\hline Euribor & $\begin{array}{l}\text { European Banking Federation } \\
\text { page www.euribor.org }\end{array}$ & $\begin{array}{l}\text { Euribor rates reflect the monetary policy that was } \\
\text { adopted for the COVID-19 period. It shows how } \\
\text { the monetary policy changed during this period. } \\
\text { The variable is reflecting the weekly change in } \\
\text { percentage points. }\end{array}$ \\
\hline $\begin{array}{l}\text { Stringency } \\
\text { index }\end{array}$ & $\begin{array}{l}\text { www.ourworldindata.org } \\
\text { (Roser et al. 2020) }\end{array}$ & $\begin{array}{l}\text { The index ranges from } 0 \text { to } 100 \text {, reflecting the } \\
\text { government's strictness to take measures (e.g., } \\
\text { lockdown) to stop the spread of COVID-19. }\end{array}$ \\
\hline New cases & $\begin{array}{l}\text { www.ourworldindata.org } \\
\text { (Roser et al. 2020) }\end{array}$ & $\begin{array}{l}\text { Daily growth in new cases per million in } \\
\text { percentage. }\end{array}$ \\
\hline Death cases & $\begin{array}{l}\text { www.ourworldindata.org } \\
\text { (Roser et al. 2020) }\end{array}$ & $\begin{array}{l}\text { Daily growth in new deaths per million in } \\
\text { percentage. }\end{array}$ \\
\hline
\end{tabular}

new cases reached 1640.91\% (from May 28 to May 29) and a minimum of -326.63\% (from June 2 to June 3). As a result, the same variation is valid for the growth in death cases ranging from -100 up to $1800 \%$. Consequently, Table A.2 in Appendix provides the correlation between the variables used in the study.

Table 2: Descriptive statistics.

\begin{tabular}{|c|c|c|c|c|c|c|c|}
\hline & $\begin{array}{l}\text { Stock } \\
\text { return }\end{array}$ & $\begin{array}{r}\text { Market } \\
\text { value }\end{array}$ & Employees & Euribor & $\begin{array}{r}\text { Stringency } \\
\text { index }\end{array}$ & $\begin{array}{r}\text { New } \\
\text { cases }\end{array}$ & $\begin{array}{r}\text { New } \\
\text { deaths }\end{array}$ \\
\hline Mean & -0.02 & -2.51 & 0.00 & 0.06 & 52.02 & 37.08 & 71.13 \\
\hline SD & 3.04 & 2.52 & 0.11 & 1.10 & 23.84 & 168.12 & 236.51 \\
\hline Min & -12.28 & -10.82 & -27.20 & -8.88 & 2.78 & -326.63 & -100.00 \\
\hline Max & 16.00 & 5.39 & 8.69 & 9.75 & 87.96 & 1640.91 & 1800.00 \\
\hline Skewness & 0.54 & 0.46 & -191.73 & 1.07 & 0.12 & 6.70 & 4.81 \\
\hline Kurtosis & 7.51 & 3.06 & 50332.90 & 24.32 & 2.10 & 62.66 & 31.24 \\
\hline
\end{tabular}

Source: Authors' calculations using the Eikon Reuters Database (2020). 


\section{Methodology and Empirical Results}

\subsection{Methodology}

Following So Im et al. (1999) and Baltagi et al. (2009), the authors adopted panel data regression to control heterogeneity across firms and identify time-varying relationships between the stock returns and all regressors. The pandemic reached a peak gradually, which persisted for several days. In formal terms, the panel regression model is given by:

$$
\mathrm{SR}_{i, d}=\alpha+\beta \operatorname{Covid}_{i, d}+\lambda Z_{d}+\Phi X_{i, d}+\phi_{i}+\gamma_{t}+\mu_{i d}(1)
$$

where $\mathrm{SR}_{i, d}$ is the stock return of the firm $i$ at day $d$. While Covid ${ }_{i, d}$ is a matrix that identifies the impact of COVID-19 cases measured by (growth of COVID-19 cases and growth of death cases) on the stock returns, $X_{i, d}$ is a matrix of regressions that includes the daily firm observables, market value and employee growth. $Z_{d}$ is a vector that includes the European money market measured by daily Euribor rates. Here $\phi_{i}$ is the firm fixed effects, $\gamma_{t}$ is the month fixed effects, and $\mu_{i d}$ is the error term that is assumed to be independently identically distributed (IID). The author adopts clustered standard errors (by firm) throughout all the regressions to address heteroskedasticity and autocorrelation problems.

\subsection{Empirical Results}

Table 3 reports the panel data regression results. On the one hand, the market value growth has consistent positive effects on French firms' stock returns. On the other hand, the change in the number of employees, which serves as a proxy for the firm size and cost commitments, shows a negative effect on the stock returns. Job losses are negatively affecting the firms operating in the market; in particular, each $1 \%$ growth in employees is associated with a reduction in the stock returns by $0.29 \%$.

Regarding the monetary policy effects, the results show that the higher the Euribor rates, the lower the stock returns become. During a pandemic crisis, monetary policy is still playing an essential role in the financial markets (Sami et al. 2020). Each one percentage point change in Euribor rates is associated with a $0.08 \%$ decrease in the stock returns. Additionally, the stringency index, which reflects the government actions, plays a vital role in alleviating the stock returns' adverse effects. Conspicuously, more restrictive measures are expected to reduce the number of new cases/deaths, saving the stock market from substantial losses. 
Table 3: Panel regression.

\begin{tabular}{llll}
\hline & $(\mathbf{1})$ & $\mathbf{( 2 )}$ & (3) \\
Dependent variable: stock return & All Firms & All Firms & All Firms \\
\hline Market value & $0.9283^{\star \star \star}$ & $1.0496^{\star \star \star}$ & $1.0862^{\star \star \star}$ \\
& $(0.1013)$ & $(0.1042)$ & $(0.1185)$ \\
Employees & $-0.2954^{\star \star \star}$ & $-0.2964^{\star \star \star}$ & $-0.3236^{\star \star \star}$ \\
Euribor & $(0.0851)$ & $(0.0885)$ & $(0.0711)$ \\
& $-0.0835^{\star \star \star}$ & $-0.0867^{\star \star \star}$ & $-0.0884^{\star \star \star}$ \\
Stringency index & $(0.0118)$ & $(0.0120)$ & $(0.0121)$ \\
& $0.0350^{\star \star \star}$ & $0.0373^{\star \star \star}$ & $0.0377^{\star \star \star}$ \\
New cases & $(0.0016)$ & $(0.0017)$ & $(0.0019)$ \\
& & $-0.0004^{\star \star \star}$ & \\
New deaths & & $(0.0001)$ & \\
Constant & & & $-0.0003^{\star \star \star \star}$ \\
Observations & & & $(0.0000)$ \\
R-squared & $1.3930^{\star \star \star}$ & $1.1126^{\star \star \star}$ & $-0.9490^{\star \star \star}$ \\
Firm FE & $(0.1930)$ & $(0.2150)$ & $(0.2754)$ \\
Month FE & 84,392 & 71,362 & 67,025 \\
\hline
\end{tabular}

The table includes all the French Firms from January 23, 2020, to October 30, 2020. Clustered standard errors in parentheses ${ }^{* \star *} p<0.01,{ }^{\star *} p<0.05,{ }^{\star} p<0.1$.

The results show that COVID-19 adverse effects on the stock market returns. The French firms' stock market has consistently suffered from losses during the COVID-19 outbreak; for instance, for each $10 \%$ growth in the daily new cases, the stock market returns decrease by $0.004 \%$.

\section{Empirical Analysis Based on Sectors, Long Debt Status, and Crisis Management}

\subsection{Classification of Listed Firms Based on the Sector of Activity}

Table 4 provides the results of the effects of COVID-19 on the stock returns of listed firms in France on the sectoral level. Panel (A) presents the regression results of daily COVID-19 cases, while panel (B) shows the daily growth rate of death cases. The table shows that the pandemic's effect on the stock returns is different across sectors on the firm level, where the sectors do not respond in the same manner to 


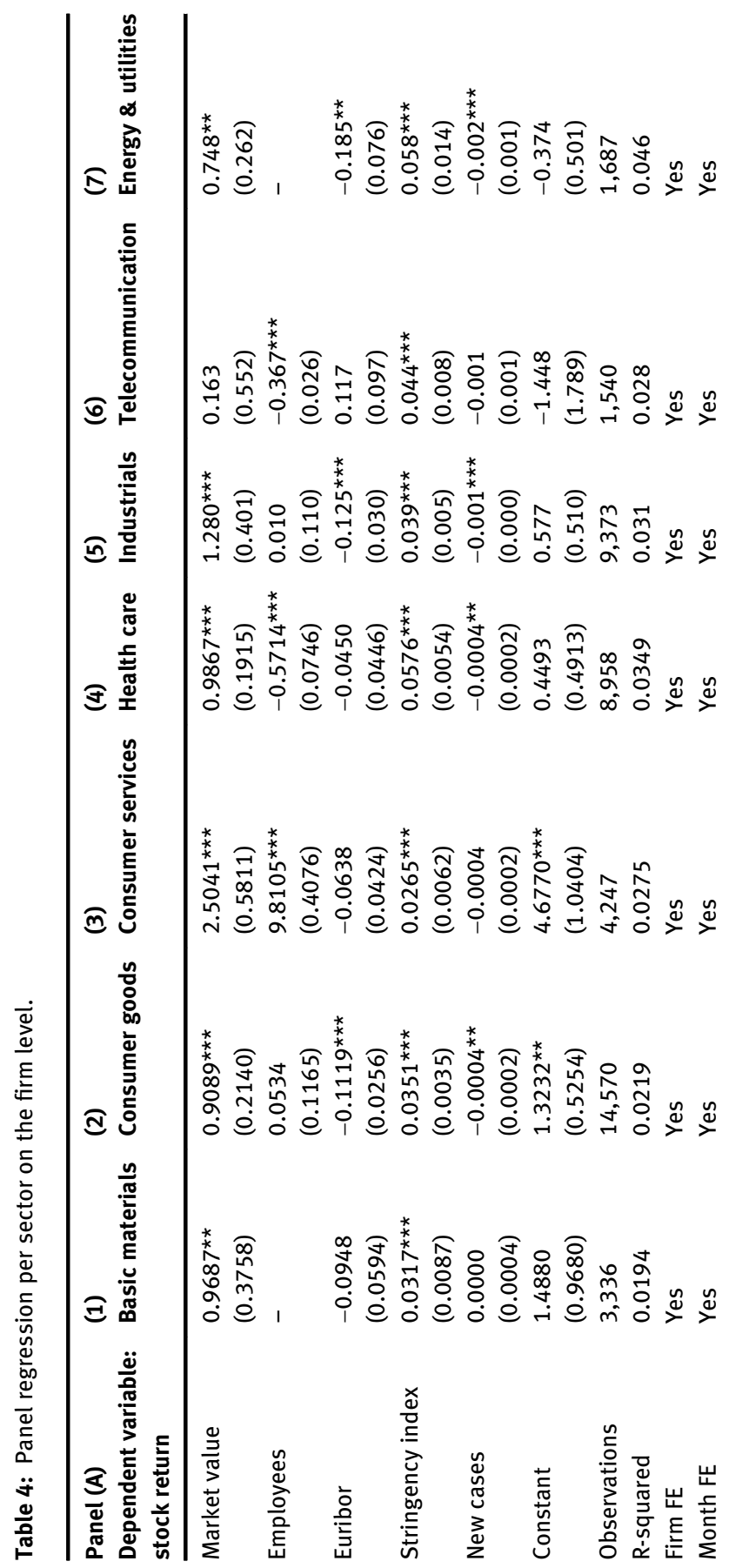




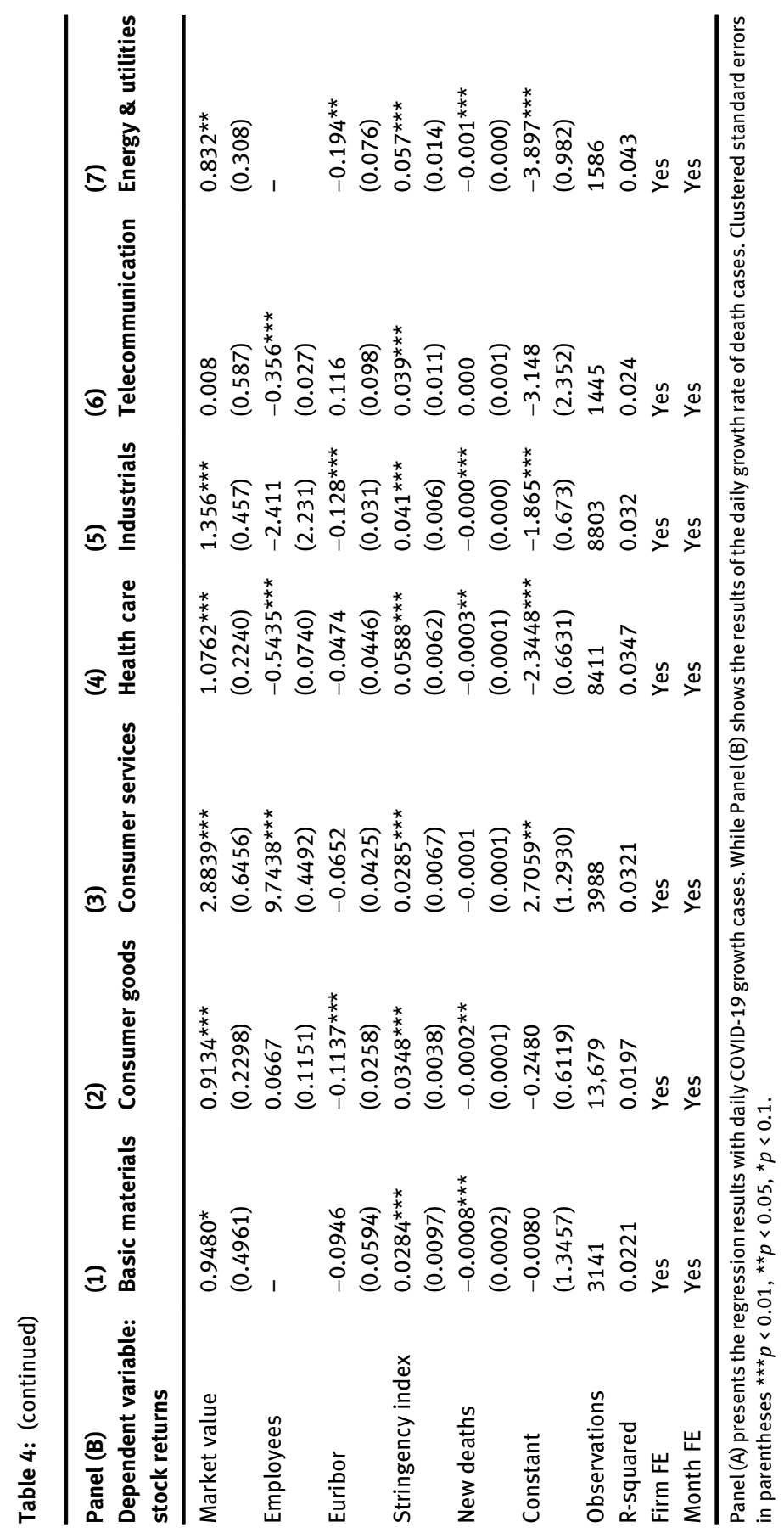


COVID-19. The employee's variable is omitted from basic material and energy sectors as there is no variability over time in those sectors. Thus, the results show that the market value plays a vital role for all sectors except telecommunication and consumer services. Moreover, the consumer service sector is the top responsive sector to the market value variable. Each $1 \%$ increase in the market value is associated with a $2.5 \%$ increase in the firms' stock returns operating in the sector. Unsurprisingly, reducing the number of employees in the telecommunication and health care sectors is associated with a significant decrease in the stock market returns. Additionally, by looking at the monetary policy variable, the results show that Euribor rates are mainly affecting three sectors in the French economy: energy, industrials, and consumer goods; accordingly, the stringency index plays a significant role across all the sectors.

According to Panel (A) and Panel (B), energy and utilities, industrial, and health care are considered the most responsive pandemic sectors. In particular, each $10 \%$ increase in the new cases is associated with a $0.02 \%$ reduction in the stock returns of the firms operating in the energy sector. The stock returns decrease by $0.01 \%$ for each $10 \%$ increase in the new COVID-19 cases for the industrial sector. On the other hand, the stock returns in health care services decrease by $0.004 \%$ for each $10 \%$ increase in the new COVID-19 cases. However, telecommunication is the least affected, which describes why this sector is mainly affected by reducing employees' number. Telecommunication and consumer services sectors were the most important for the French people as they were always operating during the crisis.

\subsection{Classification Based on the Debt Status}

Firms are classified into two main new panels. Panel (A) includes the firms with the lowest long-term debt as a percentage of market capitalization in the year preceding the pandemic disease (mainly at least $25 \%$ of firms). While Panel (B) has all the firms with long-term debt status as a percentage of market capitalization (mostly top 25\%). The findings show that the market value is still playing an important role, especially for high debt firms. Additionally, monetary policy is more effective with high debt firms; in particular, each one percentage point change in Euribor rates is associated with a $0.088 \%$ decrease in the stock returns. Regressions (1) and (2) show that monetary policy is inefficient during the pandemic period with low debt firms. Moreover, the stringency index positively affects the stock market returns for low and high debt firms. However, firms with high debt are operating much worse than those with low long-term debt commitments.; thus, this finding goes in parallel with the study (Fungáčová et al. 2020). The firms' revenue is negatively affected by 
pandemic diseases, causing the weight of debt and its solvability to be questioned for high debt firms (Table 5).

\subsection{Classification of Listed Firms Based on the Crisis Management System}

Table 6 reports the results by distinguishing two firms' panels to understand the crisis management system's importance. Panel (A) does not have a crisis management system, while Panel (B) has a crisis Management system. The firm is reported to have this system if it has a contingency plan to resume business with minimum downtime while ensuring that companies can remain operational through any unexpected event. The author notes that the observations are much lower than the previous results as the data's information is missing for an actual number of firms. Having a closer look at the table below, the firms with a crisis management system are less responsive to monetary policy than firms with a crisis

Table 5: Panel regression on the firm level: debt status.

\begin{tabular}{|c|c|c|c|c|}
\hline $\begin{array}{l}\text { Dependent variable: } \\
\text { Stock returns }\end{array}$ & $\begin{array}{l}\text { (1) } \\
\text { Panel (A) }\end{array}$ & $\begin{array}{l}(2) \\
\text { Panel (A) }\end{array}$ & $\begin{array}{l}\text { (3) } \\
\text { Panel (B) }\end{array}$ & $\begin{array}{l}\text { (4) } \\
\text { Panel (B) }\end{array}$ \\
\hline Market value & $\begin{array}{l}0.4858^{\star \star \star} \\
(0.1582)\end{array}$ & $\begin{array}{l}0.3978^{\star \star} \\
(0.1889)\end{array}$ & $\begin{array}{l}1.0610^{\star \star \star} \\
(0.1768)\end{array}$ & $\begin{array}{l}1.0907^{\star \star \star} \\
(0.1920)\end{array}$ \\
\hline Employees & $\begin{array}{l}-0.3270^{\star \star \star \star} \\
(0.0589)\end{array}$ & $\begin{array}{l}-0.3184^{\star \star \star} \\
(0.0600)\end{array}$ & $\begin{array}{l}0.3230 \\
(0.5354)\end{array}$ & $\begin{array}{l}0.3353 \\
(0.5299)\end{array}$ \\
\hline Euribor & $\begin{array}{l}-0.0013 \\
(0.0281)\end{array}$ & $\begin{array}{l}-0.0016 \\
(0.0283)\end{array}$ & $\begin{array}{l}-0.0855^{\star \star \star} \\
(0.0193)\end{array}$ & $\begin{array}{l}-0.0878^{\star \star \star} \\
(0.0195)\end{array}$ \\
\hline Stringency index & $\begin{array}{l}0.0335^{\star \star \star} \\
(0.0040)\end{array}$ & $\begin{array}{l}0.0339 * \star \star \\
(0.0047)\end{array}$ & $\begin{array}{l}0.0353^{\star \star \star} \\
(0.0028)\end{array}$ & $\begin{array}{l}0.0347^{\star \star \star} \\
(0.0029)\end{array}$ \\
\hline New cases & $\begin{array}{l}-0.0001 \\
(0.0002)\end{array}$ & & $\begin{array}{l}-0.0005^{\star \star \star} \\
(0.0001)\end{array}$ & \\
\hline New deaths & & $\begin{array}{l}-0.0001 \\
(0.0001)\end{array}$ & & $\begin{array}{l}-0.0003^{\star \star \star} \\
(0.0001)\end{array}$ \\
\hline Constant & $\begin{array}{l}0.7119 \\
(0.5925)\end{array}$ & $\begin{array}{l}-1.6256^{\star \star} \\
(0.7267)\end{array}$ & $\begin{array}{l}1.3024^{\star \star \star} \\
(0.3706)\end{array}$ & $\begin{array}{l}-0.4484 \\
(0.4489)\end{array}$ \\
\hline Observations & 13,795 & 12,952 & 25,945 & 24,367 \\
\hline R-squared & 0.0148 & 0.0147 & 0.0224 & 0.0209 \\
\hline Firm FE & Yes & Yes & Yes & Yes \\
\hline Month FE & Yes & Yes & Yes & Yes \\
\hline
\end{tabular}

Panel (A) includes the firms with low long-term debt as a percentage of market capitalization in the year preceding the pandemic (the least $25 \%$ ). While Panel (B) includes the firms with high long-term debt as a percentage of market capitalization in the year preceding the pandemic (top 25\%). Clustered standard errors in parentheses ${ }^{\star \star \star} p<0.01,{ }^{\star \star} p<0.05,{ }^{\star} p<0.1$. 
management system. The effect of the stringency index is the same across all panels. Conspicuously, all the firms are negatively affected by the pandemic crisis. However, those that have a crisis management system perform better than the firms that do not have such a system (Singh and LaBrosse 2012).

\section{Robustness Checks}

As a robustness check, the author uses daily new cases per 100,000 population instead of growth in daily new cases. ${ }^{2}$ An interaction term between stringency index and new death cases per 100,000 population variables is constructed to identify government policies' effect given the pandemic's spread in France.

Table 7 presents the main results using the number of new cases per 100,000 and demonstrates government policies' effect by interacting this variable with the

Table 6: Panel regression on the firm level: crisis management system.

\begin{tabular}{lllll}
\hline $\begin{array}{l}\text { Dependent variable: } \\
\text { Stock returns }\end{array}$ & $\begin{array}{l}(\mathbf{1}) \\
\text { Panel (A) }\end{array}$ & $\begin{array}{l}\text { (2) } \\
\text { Panel (A) }\end{array}$ & $\begin{array}{l}\text { (3) } \\
\text { Panel (B) }\end{array}$ & $\begin{array}{l}\text { (4) } \\
\text { Panel (B) }\end{array}$ \\
\hline Market value & $2.2637^{\star \star \star}$ & $2.3017^{\star \star \star}$ & $2.1734^{\star \star \star}$ & $2.1014^{\star \star \star}$ \\
& $(0.7831)$ & $(0.7199)$ & $(0.6515)$ & $(0.6024)$ \\
Euribor & $-0.2123^{\star \star \star}$ & $-0.2078^{\star \star \star}$ & $-0.1012^{\star \star}$ & $-0.0981^{\star \star}$ \\
& $(0.0507)$ & $(0.0500)$ & $(0.0435)$ & $(0.0434)$ \\
Stringency index & $0.0677^{\star \star \star}$ & $0.0668^{\star \star \star}$ & $0.0578^{\star \star \star}$ & $0.0558^{\star \star \star}$ \\
& $(0.0065)$ & $(0.0061)$ & $(0.0084)$ & $(0.0072)$ \\
New cases & $-0.0006^{\star \star \star}$ & & $-0.0005^{\star \star \star}$ & \\
& $(0.0001)$ & & $(0.0001)$ & \\
New deaths & & $-0.0008^{\star \star}$ & & $-0.0005^{\star}$ \\
& & $(0.0003)$ & & $(0.0002)$ \\
Constant & $-4.6904^{\star \star \star}$ & $-3.4333^{\star \star \star}$ & $-8.0840^{\star \star \star}$ & $-4.8170^{\star \star \star}$ \\
& $(0.4587)$ & $(0.4941)$ & $(1.3787)$ & $(1.0941)$ \\
Observations & 2581 & 2747 & 2952 & 3144 \\
R-squared & 0.0564 & 0.0611 & 0.0547 & 0.0495 \\
Firm FE & YES & YES & YES & YES \\
Month FE & YES & YES & YES & YES \\
\hline
\end{tabular}

Panel (A) includes all firms that confirmed that they do not have a crisis management system. While Panel (B) includes all firms that announced having a crisis management system. Clustered standard errors in parentheses ${ }^{* *} p<0.01,{ }^{* *} p<0.05,{ }^{*} p<0.1$.

2 The new cases per 100,000 on a daily basis (smoothed) is used as per the definition of Our World in Data. 
Table 7: Panel regression.

\begin{tabular}{llll}
\hline Variables & (1) & (2) & (3) \\
All firms & All firms & All firms \\
\hline Market value & $0.9283^{\star \star \star}$ & $0.9265^{\star \star \star}$ & $0.7942^{\star \star \star}$ \\
Employees & $(0.1013)$ & $(0.1012)$ & $(0.0951)$ \\
& $-0.2954^{\star \star \star}$ & $-0.2964^{\star \star \star}$ & $-0.3072^{\star \star \star}$ \\
Euribor & $(0.0851)$ & $(0.0852)$ & $(0.0838)$ \\
& $-0.0835^{\star \star \star}$ & $-0.0782^{\star \star \star}$ & $-0.0977^{\star \star \star}$ \\
Stringency index & $(0.0118)$ & $(0.0118)$ & $(0.0122)$ \\
& $0.0350^{\star \star \star}$ & $0.0360^{\star \star \star}$ & \\
Number of cases & $(0.0016)$ & $(0.0017)$ & \\
& & $-0.0145^{\star \star \star}$ & \\
Number of deaths $\times$ stringency index & & $(0.0032)$ & \\
Constant & & & $0.0083^{\star \star \star}$ \\
& & & $(0.0009)$ \\
Observations & $1.3930^{\star \star \star}$ & $1.3775^{\star \star \star}$ & $1.5400^{\star \star \star}$ \\
R-squared & $(0.1930)$ & $(0.1932)$ & $(0.1834)$ \\
Firm FE & 84,392 & 84,392 & 84,392 \\
Month FE & 0.0145 & 0.0147 & 0.0071 \\
\hline
\end{tabular}

The table includes all the French Firms from January 23, 2020, to October 30, 2020. Clustered standard errors in parentheses ${ }^{\star * *} p<0.01,{ }^{\star *} p<0.05,{ }^{*} p<0.1$.

number of deaths one. The results in column (2) show that for each 100,000 increase in new cases, the stock market returns decrease by $0.014 \%$. Moreover, the stringency index's government policies are still efficient during the COVID-19 period (column 3). Conspicuously, the strict policies (e.g., stay at home) by the government can positively affect the stock market returns given the increase of the pandemic's effect in France.

Table 8 reaches the same results provided by Table 4, where Panel (A) shows that the health care, industrial and energy sectors are the sectors that are the most adversely affected by the spread of the pandemic. Everything held constant, for every 100,000 new cases: (1) the stock returns of the energy sector decreases by $0.055 \%$ (2) the stock returns of the industrial sector decreases by $0.014 \%$ (3) the stock returns of the health care sector decreases by $0.023 \%$. On the other hand, Euribor rates still play an essential role in determining the stock market returns of the companies operating in consumer goods, industrial, and energy sectors.

Having a closer look at Panel (B), although the pandemic has considerably spread, the stringency index shows that it is positively affecting the stock returns of the consumer goods, health care, and the industrial sectors. On the other hand, the 


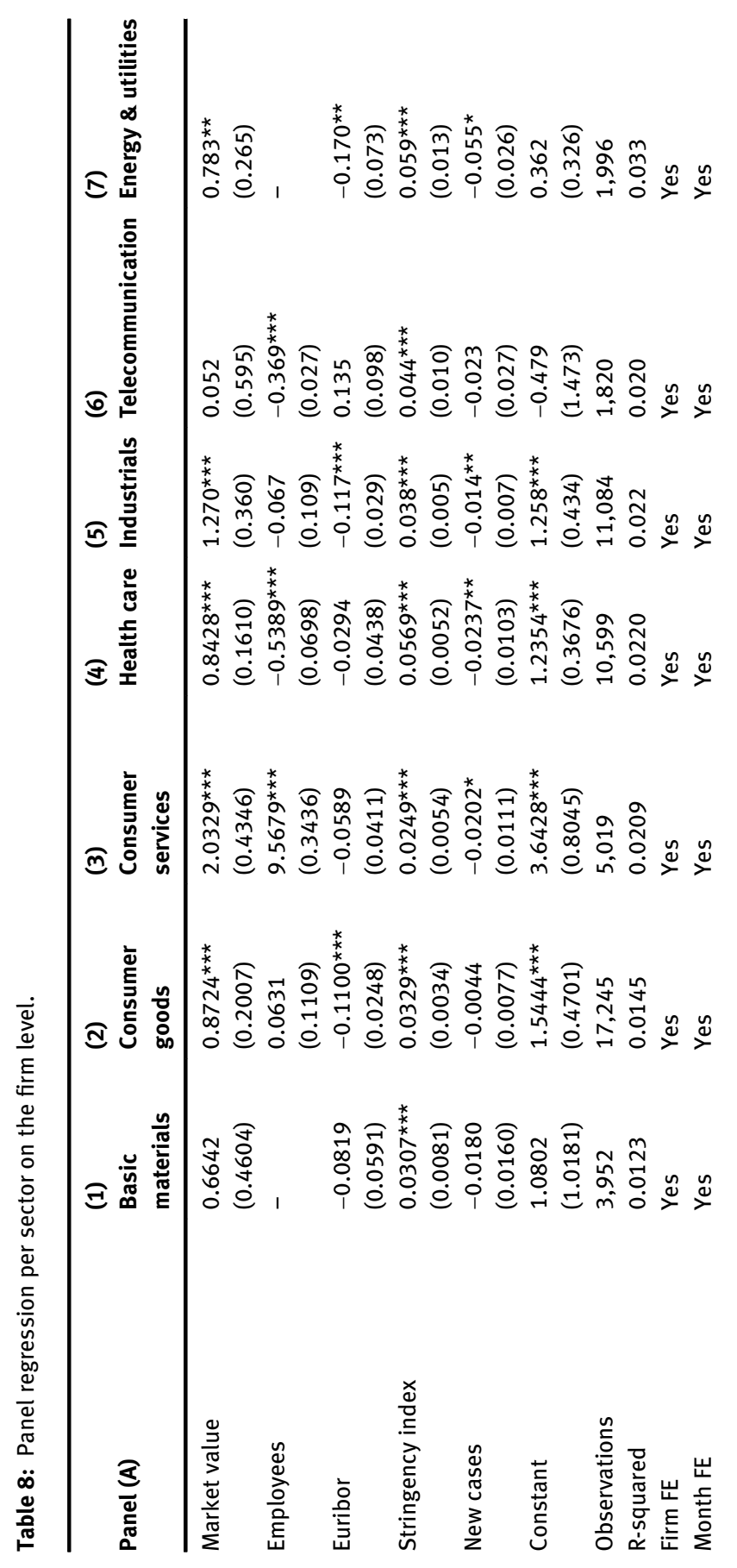




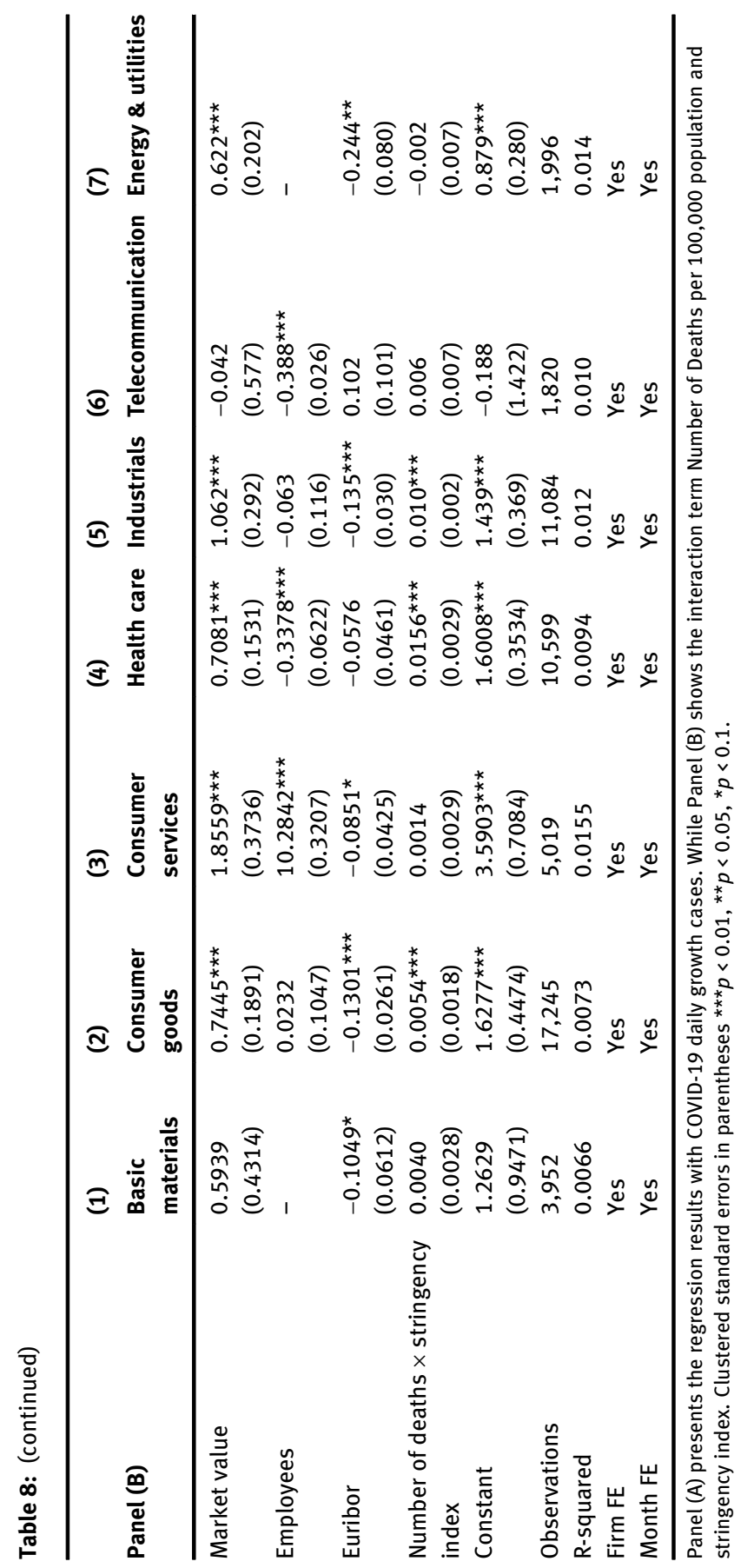


pandemic's effect turns to be insignificant for the basic materials, consumer services, telecommunication and energy sectors.

Table 9 provides the same results offered by Table 5. Panel (A) includes the firms with the lowest long-term debt as a percentage of market capitalization in the year preceding the pandemic disease (mainly the least $25 \%$ of firms). In comparison, Panel (B) has all the firms with long-term debt status as a percentage of market capitalization (mainly the top 25\%). The results show that the more committed firms to long-term debt are adversely affected by the pandemic's effect (columns 3 and 4), while the less committed firms to long-term debt are less affected (columns 1 and 2). On the other hand, the stringency index plays an essential role in reducing low and high debt firms' adverse effects.

Table 10 provides the results of the crisis management system during the pandemic crisis. Panel (A) provides the consequences related to the firms that do not have a crisis management system, while Panel (B) reports the results of the firms who have this system. As previously noted, the number of observations is

Table 9: Panel regression on the firm level: debt status.

\begin{tabular}{lllll}
\hline Variables & $\begin{array}{l}\text { (1) } \\
\text { Panel (A) }\end{array}$ & $\begin{array}{l}\text { (2) } \\
\text { Panel (A) }\end{array}$ & $\begin{array}{l}\text { (3) } \\
\text { Panel (B) }\end{array}$ & $\begin{array}{l}\text { (4) } \\
\text { Panel (B) }\end{array}$ \\
\hline Market value & $0.3593^{\star \star}$ & 0.2722 & $0.9361^{\star \star \star}$ & $0.8046^{\star \star \star}$ \\
& $(0.1752)$ & $(0.1661)$ & $(0.1590)$ & $(0.1483)$ \\
Employees & $-0.3287^{\star \star \star}$ & $-0.3399^{\star \star \star}$ & -0.1001 & $-0.1704^{\star}$ \\
& $(0.0601)$ & $(0.0575)$ & $(0.0793)$ & $(0.0994)$ \\
Euribor & -0.0000 & -0.0123 & $-0.0758^{\star \star \star}$ & $-0.0969^{\star \star \star}$ \\
& $(0.0278)$ & $(0.0281)$ & $(0.0191)$ & $(0.0197)$ \\
Stringency index & $0.0321^{\star \star \star}$ & & $0.0338^{\star \star \star}$ & \\
New cases & $(0.0040)$ & & $(0.0027)$ & \\
& -0.0032 & & $-0.0163^{\star \star \star}$ & \\
Number of deaths $\times$ stringency index & $(0.0085)$ & & $(0.0056)$ & \\
Constant & & $0.0086^{\star \star \star}$ & & $0.0069^{\star \star \star}$ \\
& & $(0.0020)$ & & $(0.0013)$ \\
Observations & 0.7581 & 0.8525 & $1.5074^{\star \star \star}$ & $1.6318^{\star \star \star}$ \\
R-squared & $(0.5642)$ & $(0.5378)$ & $(0.3247)$ & $(0.3071)$ \\
Firm FE & 16,312 & 16,312 & 30,681 & 30,681 \\
Month FE & 0.0091 & 0.0037 & 0.0139 & 0.0066 \\
\hline
\end{tabular}

Panel (A) includes the firms with low long-term debt as a percentage of market capitalization in the year preceding the pandemic (the least $25 \%$ of firms). While Panel (B) includes the firms with high long-term debt as a percentage of market capitalization in the year preceding the pandemic (Top 25\%). Clustered standard errors in parentheses ${ }^{\star \star *} p<0.01,{ }^{\star \star} p<0.05,{ }^{*} p<0.1$. 
Table 10: Panel regression on the firm level: crisis management system.

\begin{tabular}{|c|c|c|c|c|}
\hline Variables & $\begin{array}{l}\text { (1) } \\
\text { Panel (A) }\end{array}$ & $\begin{array}{l}\text { (2) } \\
\text { Panel (A) }\end{array}$ & $\begin{array}{l}\text { (3) } \\
\text { Panel (B) }\end{array}$ & $\begin{array}{l}\text { (4) } \\
\text { Panel (B) }\end{array}$ \\
\hline Market value & $\begin{array}{l}2.2230^{\star * \star} \\
(0.5748)\end{array}$ & $\begin{array}{l}1.5789^{\star \star \star} \\
(0.3476)\end{array}$ & $\begin{array}{l}1.9432^{\star \star \star} \\
(0.4768)\end{array}$ & $\begin{array}{l}1.5125^{\star \star \star} \\
(0.4019)\end{array}$ \\
\hline Euribor & $\begin{array}{l}-0.1958^{\star \star \star} \\
(0.0479)\end{array}$ & $\begin{array}{l}-0.2076^{\star \star \star} \\
(0.0551)\end{array}$ & $\begin{array}{l}-0.0902^{\star \star} \\
(0.0400)\end{array}$ & $\begin{array}{l}-0.1048^{\star \star} \\
(0.0437)\end{array}$ \\
\hline Stringency index & $\begin{array}{l}0.0630^{\star \star \star *} \\
(0.0063)\end{array}$ & & $\begin{array}{l}0.0525^{\star \star \star} \\
(0.0068)\end{array}$ & \\
\hline New cases & $\begin{array}{l}-0.0044 \\
(0.0164)\end{array}$ & & $\begin{array}{l}-0.0167 \\
(0.0141)\end{array}$ & \\
\hline Number of deaths $\times$ stringency index & & $\begin{array}{l}0.0208^{\star \star \star} \\
(0.0057)\end{array}$ & & $\begin{array}{l}0.0167^{\star \star \star} \\
(0.0038)\end{array}$ \\
\hline Constant & $\begin{array}{l}-2.2270^{\star \star \star} \\
(0.3745)\end{array}$ & $\begin{array}{l}-1.0992^{\star \star \star} \\
(0.2413)\end{array}$ & $\begin{array}{l}-3.5750^{\star \star \star} \\
(0.8615)\end{array}$ & $\begin{array}{l}-2.2136^{\star \star \star} \\
(0.7005)\end{array}$ \\
\hline Observations & 3,249 & 3,249 & 3,718 & 3,718 \\
\hline R-squared & 0.0464 & 0.0262 & 0.0351 & 0.0173 \\
\hline Firm FE & Yes & Yes & Yes & Yes \\
\hline Month FE & Yes & Yes & Yes & Yes \\
\hline
\end{tabular}

Panel (A) includes all firms that confirmed that they do not have a crisis management system. While Panel (B) includes all firms announced to have a crisis management system. Clustered standard errors in parentheses ${ }^{\star \star *} p<0.01,{ }^{\star \star} p<0.05,{ }^{\star} p<0.1$.

limited for this variable, and results should be interpreted with precautions. Columns (1) and (3) show insignificant coefficients for the two panels. Column (2) and Column (4) show that the stringency index during the spread of a pandemic is vital for the two panels of firms. However, this variable's effect is much more critical for firms without a crisis management system. The firms with this system are already facing higher losses from the pandemic than the firms that do not have a crisis management system. Therefore, any government action may alleviate the pandemic's adverse impact on the group of firms that do not have a crisis management system relative to the group who have this system.

\section{Conclusion}

This study provides three main results: (1) The COVID-19 has adversely affected the stock market returns for the listed firms in France. However, the sectors of the 
economy did not respond in the same manner. The results show that the energy, industrials, and health care sectors are the most negatively affected, while the telecommunication and consumer services sector were not affected. This finding goes in parallel with the first hypothesis of the study. (2) The firms that were less committed to long-term debts performed better than the firms with many long-term commitments (Hypothesis 2 of the study). (3) The crisis management system plays an essential role in reducing the pandemic's adverse shocks on the stock returns. In particular, the results show that the firms that have a crisis management system are performing better than the firms that do not have such a system (Hypothesis 3 of the study). (4) Monetary policy in Europe is still an essential resort during pandemics to face the negative consequences, especially for the energy, industrials and consumer goods sectors.

This study suggests that all economic system players should adopt several policy implications to reduce the pandemic's adverse effect on the economy and the financial market. The management should consistently guarantee an efficient crisis management system to face unexpected major events on the firm level. In addition to this, knowledge management within firms is essential to provide plans to support the firm against the crisis (Sami and El Bedawy 2019). Thus, different strategies should be adopted to face debt commitments when the firm experiences a period of shock.

On the macro level, results suggest that the government can still play two major roles through the monetary policy and the stringency of applying rules to reduce the pandemic's spread. The monetary policy is mainly affecting three strategic sectors: energy, industrials and consumer goods. On the other hand, the government's stringency is vital to save the market and the firms from collapsing. Furthermore, the most negatively affected sectors require prompt support from the government.

Further research should focus on the pandemic's impact by considering other firm indicators such as total factor productivity, marketing strategy and innovation. Some studies assume that the firms may reposition themselves after this pandemic period (Ayati 2020); therefore, more research on the market shifts and structural changes before and after the COVID-19 pandemic is necessary. It is also essential to study alternative investments that can be adopted during and after this period, such as Bitcoin usage (Sami and Abdallah 2020a, b). Finally, more studies should be done to reflect the impact of COVID-19 on individuals; for example, introducing the linkage between these crises and remittances is a critical question (Ayad and Abd El Aziz 2018). 


\section{Appendix}

Table A.1: Sample of listed firms in the data.

\begin{tabular}{lll}
\hline Audience Labs & Courtois & Saint Gobain \\
Gerard Perrier & Veolia & CNP Assurance \\
Avenir Telecom & Électricité de France & Thales \\
1000 Mercis & Tipiak & Rexel \\
Amundi & Pernod & Valeo \\
Bouygues & Gaumont & AccorHotels \\
Courbet & Hotels de Paris & Total S. A. \\
\hline
\end{tabular}

Source: Exported from the Eikon Reuters Database (2020).

Table A.2: Correlation matrix.

\begin{tabular}{lrrrrrr}
\hline & $\begin{array}{c}\text { Market } \\
\text { value }\end{array}$ & Employees Euribor & $\begin{array}{r}\text { Stringency } \\
\text { index }\end{array}$ & $\begin{array}{r}\text { New } \\
\text { cases }\end{array}$ & $\begin{array}{r}\text { New } \\
\text { deaths }\end{array}$ \\
\hline Market value & 1.00 & & & & & \\
Employees & 0.01 & 1.00 & & & & \\
Euribor & 0.00 & 0.00 & 1.00 & & & \\
Stringency & -0.02 & -0.01 & -0.05 & 1.00 & & \\
index & & & & & & \\
New cases & 0.00 & 0.00 & 0.03 & 0.05 & 1.00 & \\
New deaths & 0.00 & 0.00 & -0.01 & -0.11 & -0.11 & 1.00 \\
\hline
\end{tabular}

Source: Authors' calculations using the Eikon Reuters Database (2020).

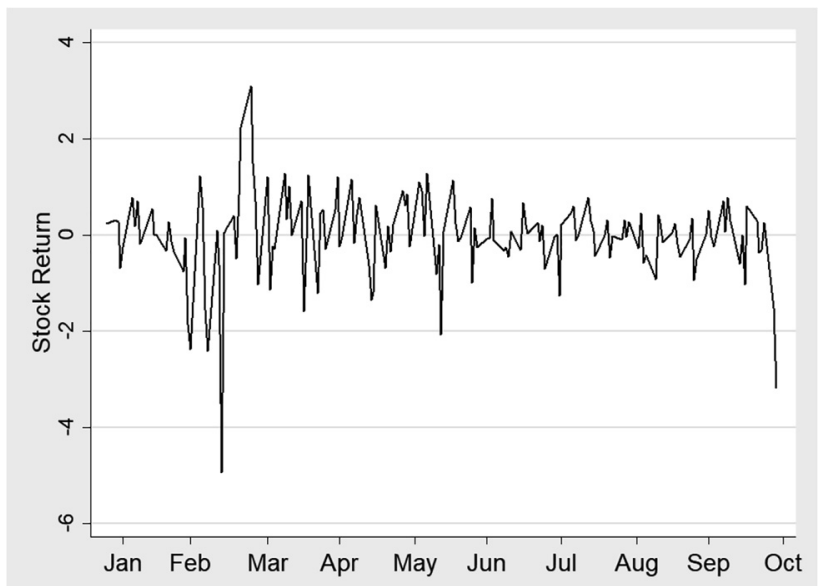

Figure A.1: Stock returns (average) variable of listed firms in France.

Source: Authors' construction using the Eikon Reuters Database (2020). The figure shows the average stock returns of the listed French Firms over the period January 23, 2020, to October 30, 2020. 


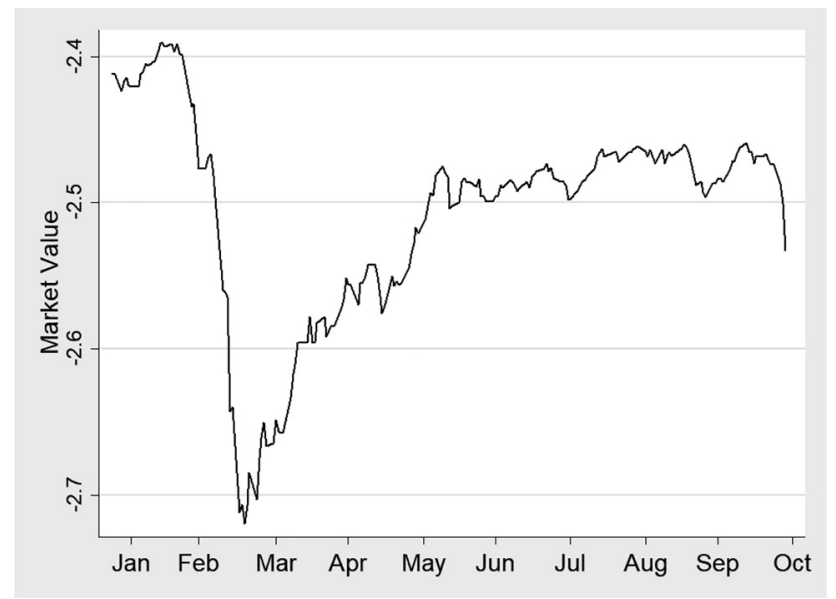

Figure A.2: Market value (average) variable of listed firms in France.

Source: Authors' construction using the Eikon Reuters Database (2020). The figure shows the average Market Value growth of the listed French Firms from January 23, 2020, to October 30, 2020.

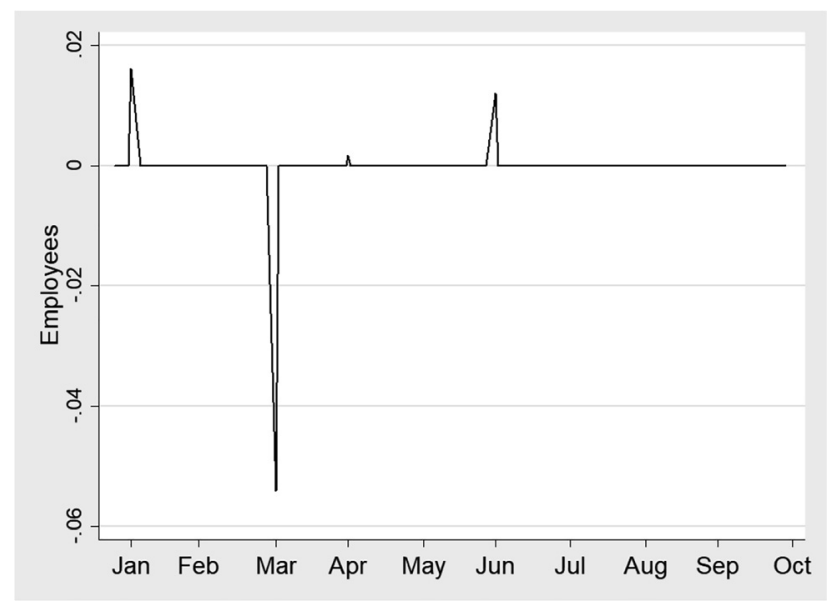

Figure A.3: Employees (average) variable of listed firms in France.

Source: Authors' construction using the Eikon Reuters Database (2020). The figure shows the average growth in the number of employees of the listed French Firms over the period January 23, 2020, to October 30, 2020. 


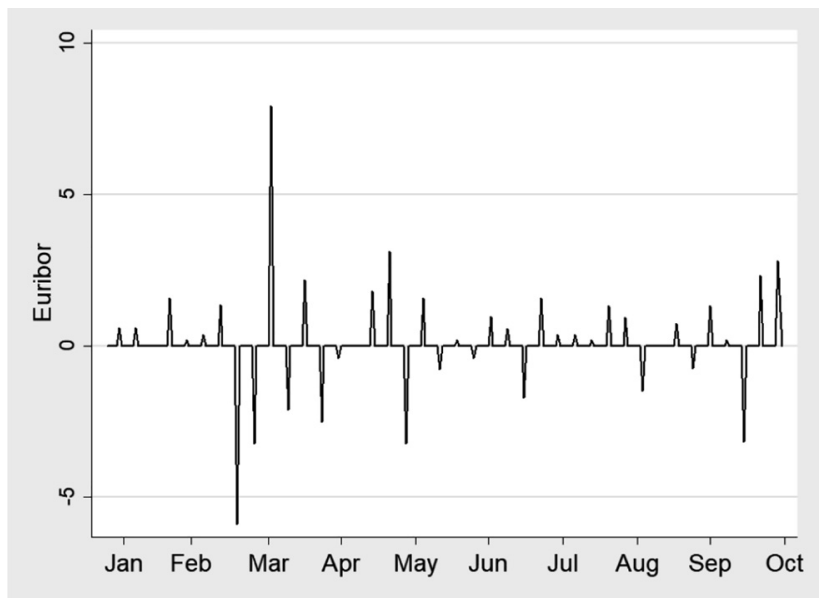

Figure A.4: Euribor rates variable during COVID-19 period.

Source: Authors' construction using the European Banking Federation page www.euribor.org. The figure shows the average Market Value growth of the listed French Firms from January 23, 2020, to October 30, 2020.

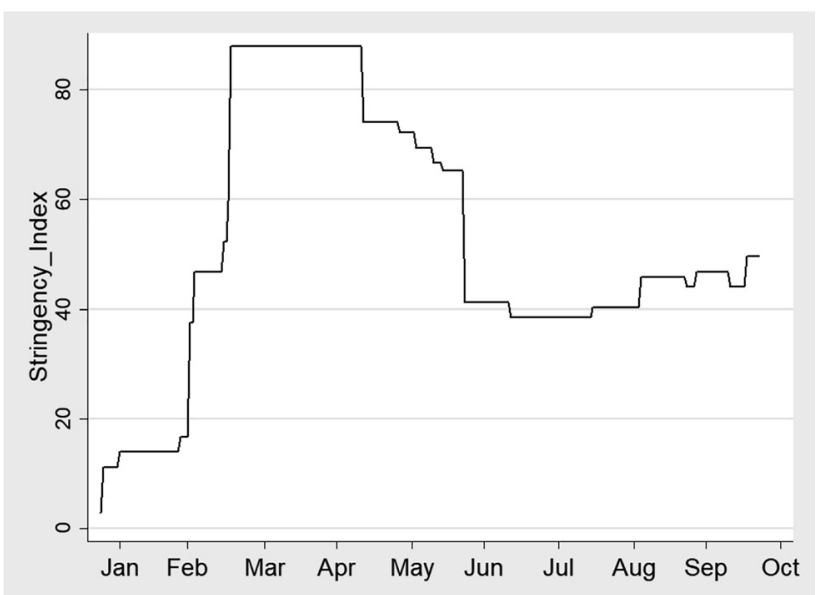

Figure A.5: Stringency index variable during COVID-19 period.

Source: Authors' construction using www.ourworldindata.org (Roser et al. 2020). The Stringency index shows the strictness of the government actions in dealing with COVID-19. 

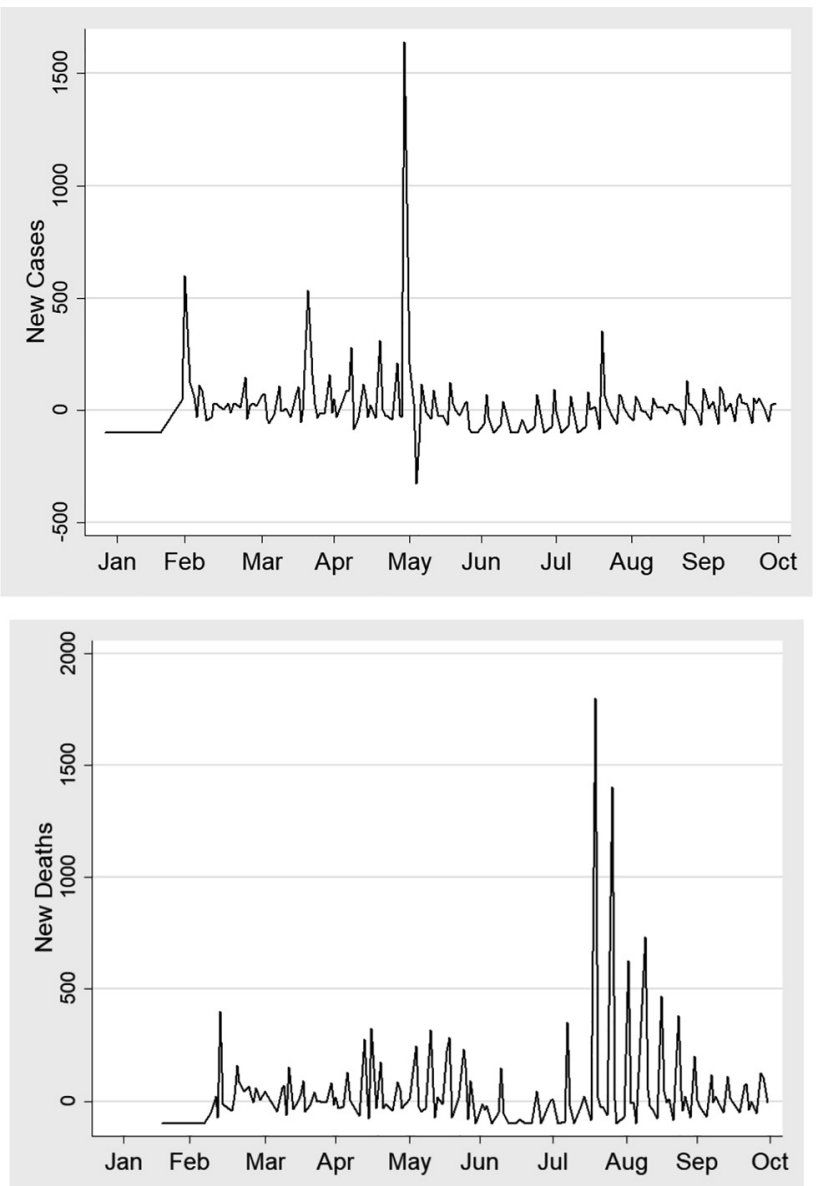

Figure A.6: New cases/deaths during COVID-19 period.

Source: Authors' construction using www.ourworldindata.org (Roser et al. 2020). The figures show the growth in new cases and deaths in France over January 23, 2020, to October 30, 2020.

\section{References}

Ayad, M. and Abd El-Aziz, A. (2018). The impact of remittances on Children's Educational Attainment: evidence from Egypt. Socioecon. Chall. 2: 49-59.

Al-Awadhi, A.M., Alsaifia, K., Al-Awadhib, A., and Alhammadi, S. (2020). Death and contagious infectious diseases: impact of the COVID-19 virus on stock market returns. J. Behav. Exp. Finance 27: 100326. 
Akhtaruzzaman, Md., Boubaker, S., and Sensoy, A. (2020). Financial contagion during COVID-19 crisis. Working Paper, Available at: https://papers.ssrn.com/sol3/papers.cfm?abstract_ id=3584898 (Accessed 3 May 2020).

Ayati, N., Saiyarsarai, P., and Nikfar, S. (2020). Short- and long-term impacts of COVID-19 on the pharmaceutical sector. DARU J. Pharmaceut. Sci. 28: 799-805.

Baltagi, B., Song, S., and Kwon, J. (2009). Testing for heteroskedasticity and spatial correlation in a random effects panel data model. Comput. Stat. Data Anal. 53: 2897-2922.

Barro, R., Ursúa, J.F., and Weng, J. (2020). The coronavirus and the Great Influenza pandemic: lessons from the "Spanish Flu" for the Coronavirus's potential effects on mortality and economic activity. NBER working papers no: 26866.

Bernard-Stoecklin, S. (2020). First cases of coronavirus disease 2019 (COVID-19) in France: surveillance, investigations and control measures, January 2020. Euro Surveill. 25: 2000094.

Bloom, D., Cadarette, D., and Sevilla, JP. (2018). Epidemics and economics. Finance Dev. 88: 46-49.

Capelle-Blancard, G. and Laguna, M. (2010). How does the stock market respond to chemical disasters? J. Environ. Econ. Manag. 59: 192-205.

Charfeddine, L. and Al Refai, H. (2019). Political tensions, stock market dependence, and volatility spillover: evidence from the recent intra-GCC crises. N. Am. J. Econ. Finance 50: 101032.

Chen, M.P., Lee, C.C., Lin, Y.H., and Chen, W.Y. (2018). Did the S.A.R.S. epidemic weaken the integration of Asian stock markets? Evidence from smooth timevarying cointegration analysis. Economic Research-Ekonomska Istraživanja 31: 908-926.

Coronavirus en France: Le Parcours des Trois patients. France Info (in French). 2020. Archived from the original on February 21, 2020. Retrieved February 26, 2020.

D'Amato, A. (2019). Capital structure, debt maturity, and financial crisis: empirical evidence from SMEs. Small Bus. Econ. 55: 919-941.

Degiannakis, S., Filis, G., and Floros, C. (2013). Oil and stock returns: evidence from European industrial sector indices in a time-varying environment. J. Int. Financ. Mark. Inst. Money 26: 175-191.

Documents.worldbank.org. (2020). [online] Available at: https://documents.worldbank.org/ curated/en/762621532535411008/pdf/128852-BR-SecM2018-0217-PUBLIC-new.pdf (Accessed 6 October 2020).

Eikon Reuters Database. (2020). Data on listed French firms, (Accessed 10 November 2020).

Fungáčová, Z., Godlewski, C., and Weill, L. (2020). Does the type of debt matter? Stock market perception in Europe. Q. Rev. Econ. Finance 75: 247-256.

He, P., Sun, Y., Zhang, Y., and Li, T. (2020). COVID-19's impact on stock prices across different sectors-an event study based on the Chinese stock market. Emerg. Mark. Finance Trade 56: 2198-2212.

INSEE (2020). Economic outlook 2020, conjoncture in France. INSEE, December 15, Paris.

Kowalewski, O., and Śpiewanowski, P. (2020). Stock market response to potash mine disasters. J. Commod. Mark. 20: 100124.

Limkriangkrai, M., Koh, S., and Durand, R. (2016). Environmental, social, and governance (ESG) profiles, stock returns, and financial policy: Australian evidence. Int. Rev. Finance 17: 461-471.

Montout, S. and Sami, M. (2016). Determinants for locating research and development activity in Europe. Int. Econ. 145: 7-20.

Qin, M., Zhang, Y.-C., and Su, C.-W. (2020). The essential role of pandemics: a Fresh insight into the oil market. Energy Res. Lett. 1: 1-6. 
Roser, M., Ritchie, H., Ortiz-Ospina, E., and Hasell, J. (2020). Coronavirus disease (COVID-19) published online at OurWorldInData.org, https://ourworldindata.org/coronavirus (Accessed 30 October 2020).

Sami, M. and El Bedawy, R. (2019). Assessing the impact of knowledge management on total factor productivity. Afr. J. Econ. Manag. Stud. (ahead-of-print), https://doi.org/10.1108/ajems-052019-0188.

Sami, M. and Eldomiaty, T. (2019). Modeling dynamic location expansion of multinational firms in France. Empir. Econ. 59: 3033-3061.

Sami, M. and Abdallah, W. (2020a). Cryptocurrency and stock market: complements or substitutes? Evidence from Gulf countries. Appl. Finance Lett. 9: 25-35.

Sami, M. and Abdallah, W. (2020b). How does the cryptocurrency market affect the stock market performance in the MENA region? J. Econ. Adm. Sci. (ahead-of-print), https://doi.org/10. 1108/JEAS-07-2019-0078.

Sami, M., Eldomiaty, T., and Kamal, M. (2020). How do fund rates affect U.S. firms? A threshold estimation. Central Bank Rev. 20: 75-84.

Sharif, A., Aloui, C., and Yarovaya, L. (2020). COVID-19 pandemic, oil prices, stock market, geopolitical risk, and policy uncertainty nexus in the U.S. economy: Fresh evidence from the wavelet-based approach. Int. Rev. Financ. Anal. 70: 101496.

Singh, D. and LaBrosse, J. (2012). Developing a Framework for effective financial crisis management. OECD J. Financ. Mark. Trends 2011: 125-154.

Sobieralski, J. (2020). COVID-19 and airline employment: insights from historical uncertainty shocks to the industry. Transp. Res. Interdiscip. Perspect. 5: 100-123.

So Im, K., Ahn, S., Schmidt, P., and Wooldridge, J. (1999). Efficient estimation of panel data models with strictly exogenous explanatory variables. J. Econom. 93: 177-201.

Zhang, D., Hu, M., and Ji, Q. (2020). Financial markets under the global pandemic of COVID19. Finance Res. Lett. Available at: https://www.sciencedirect.com/science/article/pii/ S1544612320304050 (Accessed 3 May 2020). 